\title{
Membership
}

\section{NEW ACTIVE MEMBERS}

L. L. Mercer,

VAN-50-4

Box 146,

Terrace, B.C.

Jean Berard,

11480 Pasteur St.,

Montreal, P.Q.

F. J. Hutcheson,

LW-68-4

c/o Ontario Minnesota Pulp \&

Paper,

Atikokan, Ont.

George A. Rogers,

101 Harcourt Rd,

Calgary, Alta.

T. R. Isherwood,

$9 A$ - 6th Street,

General Delivery,

Cochraine, Ont.

Jacques Favreau,

$\mathrm{CH}-68-2$

1000 Lawlor,

Apt. 309 ,

Montreal 9, P.Q.

N. Zivanovich,

253 West 18th Street,

Hamilton, Ont.

John E. Dorion,

VAN-65-1

Toba 1,

Box 5500 ,

Campbell River, B.C.

R. LaFrance,

$\mathrm{CH}-40-2$

C.I.P. Co.,

1540 Sun Life Bldg,

Montreal, P.Q.

B. W. Smith,

454 Church Street,

Fort Francis, Ont.

C. C. Bengough,

VAN-63-4

c/o Kenya, Forest Dept.

Box 30513,

Nairobi, Kenya.

\section{NEW AFFILIATE MEMBERS}

D. J. Wheatley

A-VI

c/o Rayonier Canada (BC) Ltd., Jeune Landing, B.C.

G. H. Tindale, A-VAN

4635 Inverness Street,

Vancouver 10, B.C.

Norman Flaherty

132 - 9 Avenue SW,

Calgary, Alta.

\section{NEW STUDENT MEMBERS}

E. L. Borczon, S-SO-70-2

317 Shaw Street,

Toronto, Ont.
P. K. Bidwell,

S-SO-70-2

New College Residence,

University of Toronto,

Toronto, Ont.

D. J. Richardson,

S-MAR-69-1

P.O. Box 1301

Fredericton, N.B.

John Ambrose, $\mathrm{CH}-70-5-\mathrm{S}$

Dept. of Woodlot Management

Box 500 ,

Macdonald College, P.Q.
T. R. Myland,

S-SO-70-1

184 King Street,

Weston, Ont.

Jered Z. Roth,

S-MAR-69-1

385 Canterbury Drive.

Apt. 5D

Fredericton, N.B.

J. R. Hreno,

47 Kelly's Trailer Court

Fredericton, N.B.
COMMONWEALTH FORESTRY BUREAU

\section{FORESTRY ABSTRACTS}

This quarterly journal publishes more than 6,500 abstracts per year, covering the whole field of forestry and forest products and based on scrutiny of current world forestry literature. Publications from 90 countries in mare than 30 languages are dealt with. Each issue normally includes a comprehensive review of some particular forestry subject. Annual subscription per volume (plus index): For countries officially contributing to the C.A.B. organizatian 110s. For non-contributing countries 2105. $(\$ 27.50)$.

Guide to the Use of Forestry Abstracts

Includes full names and addresses of all publications noticed, and many other aids. Price 30s., including eight annual supplements, post free.

Weekly Title Card Service

A quick-service postal auxiliary to the Abstrocts, bringing to subscribers four times a month exact copies of the index cards made from the world stream of forestry literature during the Bureau's day-to-day work. Total about 8,500 annually. Full particulars and samples from: The Director, Commonwealth Forestry Bureau, Oxford.

Oxford System of Decimal Classification for Forestry $A_{5}$ approved by IUFRO, FAO and FID. Price 15s.

Russian-English Forestry and Wood Dictionary (Technical Communication No. 6) Contains translations of over 7,000 terms, supplemented where necessary by definitions and explanations, covering all aspects of forestry and the structure, conversion and utilization of woad, and includes the main forest plants and animals, with their scientific nomes. Price $35 \mathrm{~s}$.

Leading Article Series: most recent reprints

No. 39. lonizing radiations in forests and forestry (excluding the use of radio-active tracers).

No. 40. Mist precipitation on vegetation

No. 41. Application of electronic digital computers to forest research and management

Annotated Bibliographies

A series providing references from world literature, together with abstracts, in selected subjects.

No. 1. Shelterbelts and windbreaks

No. 2. Briquetting of wood waste

No. 3. Effects of felling season and length of storage on variation in weight and density of wood.

No. 4. Afrormosia (Pericopsis) in Africa

Further titles will follow.

Obtainable from -

\section{Commonwealth Agricultural Bureaux CENTRAL SALES BRANCH FARNHAM ROYAL, BUCKS., ENGLAND}

to whom all correspondence regarding publications should be addressed. 